\title{
動作モジュール駆動型ロボット運動制御システムの構築
}

\author{
片 山幸 久* 南 條 義 人* 下 倉 健一朗*
}

\section{A Motion Control System with Event-Driven Motion Module Switching Mechanism for Robotic Manipulators}

\author{
Yukihisa Katayama*, Yoshito Nanjo* and Ken-ichiro Shimokura*
}

\begin{abstract}
The new motion control system described in this paper has an event-driven motion-module switching mechanism. This mechanism can select a previously prepared motion-module for each event generated from sensor information and can modify a reference input in real-time. This highly modular and extendable motion-compensating mechanism, especially effective in robot tasks with uncertainties and in robot motion that requires skill, should be useful for such robot tasks as machining and assembling. This paper describes the concept and implementation of the proposed system and presents some experimental results demonstrating its feasibility.
\end{abstract}

Key Words: Robot Controller, Manipulator, Sensory Feedback, Event Drive, Switching

\section{1. はじめに}

\section{1 研究の背景}

近年, 生産現場におけるロボットマニピュレータの活躍は目 覚しいものがある $[1]$. このようななか, ワークの位置決め誤 差やワーク形状の個体差などが存在する不確実性の高い環境下 での組立作業, あるいは溶接やバリ取り・磨きといった熟練が 必要な作業を実現するロボットの提供が望まれている.

一方, マニピュレーションの高度化を目指して, 種々の要 素技術や高度な作業を実現する動作戦略が提案されてい る [2][3][5][9]. 一般にこれらを実現するためには，多様な センサを用い，様々な制御則や動作戦略をロボットシステムに 実装することが要求される，ところが，現用の多くの産業用口 ボットコントローラは十分なセンサインタフェースを持たず, センサデータの情報処理能力も低い，また，センサ情報に基づ く高度なマニピュレーションを実行する機能は, 設計やチュー ニングのための十分な環境が整えられていないため使いこなす ことが難しい。このような要因により，マニピュレーション高 度化を目指した研究成果の多くは，生産現場へ導入されていな いのが現状である。この解決には様々な制御則・動作戦略をモ ジュール化し，モジュール単位で設計や修整を行い実装ができ る構造を持ったコントローラが必要である.

また，現実的な作業は一連の動作シーケンスからなると考え られる．例えば，Fig.1（a)にみられるような組立作業において は, 突きあて, 辺合わせ, 面合わせといった単位動作のシーケ

原稿受付 1995 年 4 月 3 日

*NTT ヒューマンインタフェース研究所

*NTT Human Interface Laboratories
ンスにより作業を遂行することができる $[3]$ ．また, バリ取り・ 溶接などの加工作業においても, 動作開始から終了までの作業 全体を単位動作のシーケンスとみなせる．例えば Fig. 1(b) に 見るようなバリ取り作業を考えてみると, Step 1 : 開始位置へ のアプローチ (開始点の検出と位置決め), Step 2: A パート のバリ取り (バリ取り戦略 a), Step 3 : 次のバリ開始位置へ の移動, Step 4:Bパートのバリ取り（バリ取り戦略 b)，..., Step $n$ : バリ取り終了後の離脱 といったシーケンスで実現さ れる[6]. 満足のいく作業を遂行するためには, 各ステップに おいて, 戦略 $a$, 戦略 $b, \ldots$, といった適切な戦略を逐次実行 し，各ステップを確実に実行する必要がある．このような考え に基づき，本論文ではシーケンスの各ステップを確実に実行す

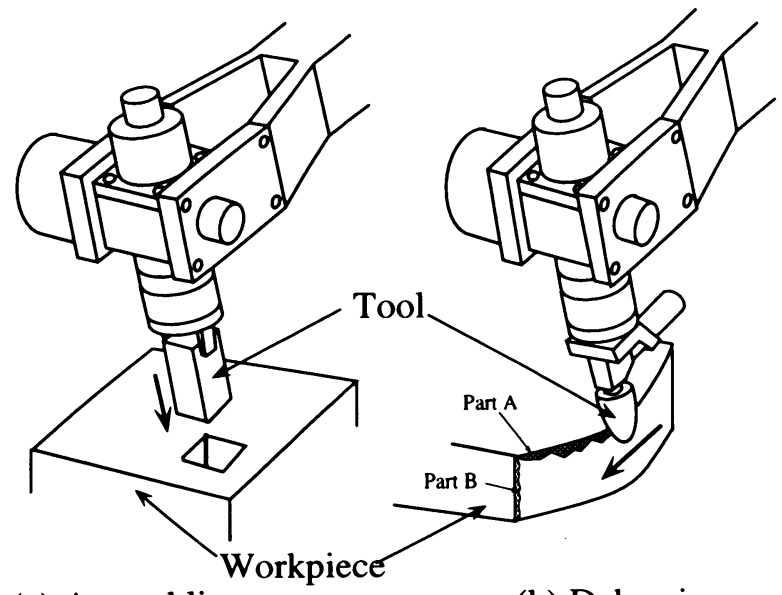

(a) Assembling

(b) Deburring

Fig. 1 Typical manipulation tasks 
る動作を単位動作と定義して用いる。この単位動作のなかで作 業中に生じる不確実性を吸収し各動作を確実に実行することに より, 各ステップのシーケンシャルな記述により作業全体の実 行がなされる。

作業を単位動作のシーケンスで記述し実行するというアイデ アは，末広らにより提案されている [3]. 文献 [3]では，凸多面 体の組立作業を対象として, プリミティブな単位動作として基 本動作（motion primitive）を抽出し，その基本動作を確実に 実行するスキルと呼ぶ機能を実現している．スキルをシーケ ンシャルに実行することにより作業全体が実現される。ここで は，凸多面体の組立作業に限定しており，他の種類の作業に対 する適用可能性は不明であるが，基本動作のシーケンスにより 作業を実行する考え方は一般的な作業に対して有効だと思われ る. 一方, 作業の解析を通じて動作の基本要素を用意すること は有効に違いないが, 単位動作の抽出は作業に依存し, 作業に よっては, あらかじめにすべての基本動作を抽出することは困 難である. 単位動作の数をプリミティブな基本動作として固定 してしまうことは，対象作業を限定してしまうことにもなりか ねない.

そこで,より複雑な作業への対応を考えると, 基本動作とい うプリミティブに限定せずに，様々な単位動作を実現すること が必要になる．そのためには，様々な単位動作を実現すること ができる共通のテンプレートとしてのメカニズムが必要となる． そこで，このようなメカニズムに必須な基本機能について考え てみる. 例えば Fig. 1 (b) に示すようなバリ取り作業について 考えてみると, 各ステップを遂行する機能の実現のためには， 熟練者のスキルを導入した運動制御レベルでのセンサフィード バックを用いることが有効であり，また，Fig.1(a)に示すよう な組立作業においては，つきあてや辺合わせといった対象物に 倣う機能が必要である. 各機能の実現のためには状態の監視と, 速度制御・カ制御・位置制御といった制御モードの切替えが必 要となる [3][4]. このように, 単位動作のなかで不確実性を吸 収するためには，環境の状況に応じた動作の修整が必要であり， 外部の状況をトリガーとしたイベントドリブンでの動作の切替 えが必須となる，すなわち，様々なセンサフィードバック制御 則の実装と, 状態を監視し, 作業状況に応じて制御則を切替え る機能が必要となる。

\section{2 従来研究}

ロボットシステムのアーキテクチャに関する研究としては, 高い自律性を目指したものが提案されているが [10]〜 [13]，こ れらの研究はコンセプトの提案にとどまり，それを実現するメ カニズム, 特に, 動作のリアルタイム性を考慮した運動を実現 するメカニズムについては十分検討されていない，また，自律 性に重点がおかれているため, 作業設計を行うための作業の記 述能力の考慮も不十分である．センサを用いたロボット制御の 実証例としては，運動制御レベルでのモデル追従制御の概念を 一般的なセンサフィードバックシステムへと拡張した仮想内部 モデル追従制御系がある [8]. しかし, 複雑な作業の実行に必 要な状態の記述法については十分な検討はされていない.一方， McGrragher らは, ペトリネットを用いて複雑な組立作業プロ セスをモデル化し，制御システムで用いている [9]. しかしな
がら制御モードは単一であり，具体的な制御系メカニズムは示 されておらず，他のタスクへの適用可能性は不明である。

本論文では, 運動制御のレベルで, サーボ周期と同程度の実 時間でのセンサフィードバックが可能であり, かつ, 状況に応 じて適切に動作モードを切替えることにより, 複数のマニピュ レーション機能（付録-A 参照）を実現可能な新たなロボット 運動制御システムのメカニズムを提案する．まず, 複数の動作 モードを切替えるうえでの問題点を考慮したうえで, 作業プロ セスとして離散的な状態を扱う運動制御システムのアーキテク チャを提案し，その構成・機能を示す，さらに実験システムを 構築し, 本メカニズムの妥当性を示す.

以下，2 章で様々なマニピュレーション機能を受容するのに 適したシステムについて考察し, システムの基本構造を提案す る. 3 章において, 提案するメカニズムの具体的な構成を述べ, 4 章でシステム設計例を，5 章で提案するメカニズムの実現可 能性と有効性を示し, 最後に 6 章に本研究で得られた成果をま とめる.

\section{2. システム概要}

\section{1 システムの基本構成}

ロボットを動作させるためには，ワールド座標における手先 ツールの位置（以下, 位置とは位置および姿勢の 6 自由度を意 味する）を指定しなければならない. 本論文ではマニピュレー ション機能をツールを操作する機能としてとらえ（付録-A を参 照)，ツール操作の基準位置のワールド座標系における指定と， その基準位置を中心とした相対的なツール操作量を考え，この 二つの量を合成して手先ツールの位置を生成する考え方を取る. これにより，作業のシーケンスにおける各段階において，ツール 操作を行う基準位置をマクロな軌道として指定し, この軌道の 記述と独立した所望のツール操作機能の指定が可能となる．す なわち, マニピュレーション機能をツール操作機能として部品化 し，汎用的に用いることができるようになる.さらに，一般的に マニピュレータのセンサフィードバック制御則は位置指令型制 御系をべースにして記述できること $[8]$ を考慮し， Fig.2(a)に 示すように, 上位プランナ (HLP-High Level Planner), ツー ル操作部 (TMG-Tool Motion Generator), サーボコントロー

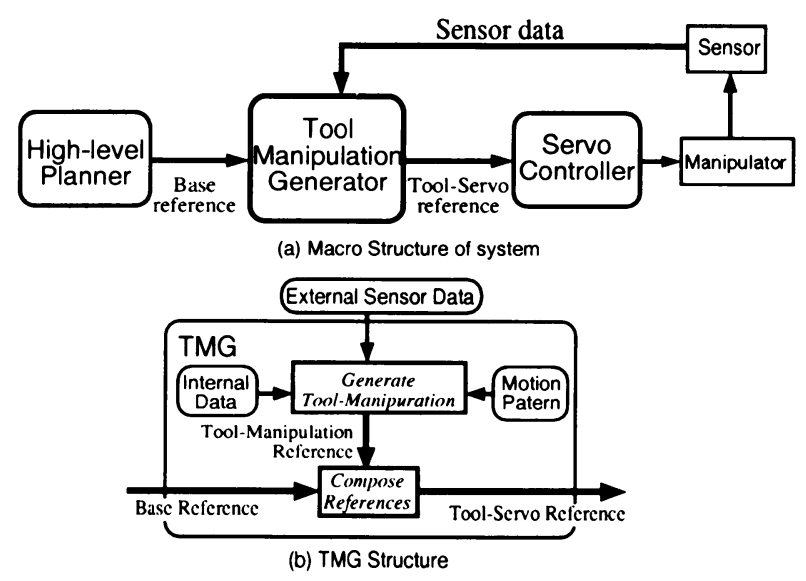

Fig. 2 Macro structure of the system 
ラ（SVC-Servo Controler）の三つのブロックからなる構成を システムの基本とする.

\section{上位プランナーHLP}

HLPにはあらかじめ動作のシーケンスをプログラミングして おき, 動作のシーケンスに応じて TMG に適切なマニピュレー ション機能を発現させる．また，ツール操作の基準位置の軌道 を生成し, ベース指令値として下位のブロックである TMGへ 出力する。ここで, TMGで用いるツール操作指令値を記述す る座標系をツール操作座標系と名付けると, ベース指令值の軌 道は, ワールド座標系におけるツール操作座標系の位置・姿勢 の軌道と意味付けすることができる．

ツールマニピュレーションジェネレーターTMG

Fig.2 (b) に示すように, TMG は外部センサ情報やコント ローラの内部情報といったリアルタイムな情報，あるいは場合 によっては，事前に設定された動作パターンに基づいてツール 操作指令值を生成する. ツール操作指令值は, ベース指令值に 対する相対的な位置指令值として生成される。このツール操作 指令值をべース指令值に合成し, ツールが追従すべきワールド 座標系上での位置指令をツールサーボ指令值として SVCへ出 力する.

また, 高度なマニピュレーション機能の実現には, 様々な動 作パターンや種々のセンサ情報に基づく制御則の実装と, 内部 外部のセンサ情報を用いた状態監視の結果に基づく制御則の切 替えが必要であり，これらの機能を TMGが担う。

\section{サーボコントローラーSVC}

SVC はワールド座標系上で記述されるツールサーボ指令値に 追従するように，ロボットを制御する。

以上の構成は結果として, 仮想内部モデル追従制御システ ム [8] と同様なものになっているが, TMG はマニピュレーショ ン機能を実現するツール操作を担うブロックとして位置づけら れる．これは，必ずしもセンサ情報に基づく動作を生成する必 要はなく, バリ取りにおけるグラインダの摇動動作 [7] などの ような, ツールを巧みに使うための定型パターンを生成するこ とも可能である．本論文では，マニピュレーション機能を実現 するための TMGについて，具体的なアーキテクチャに重点を おいて述べる. HLP は単に上述のベース指令值の軌道を生成 する目標軌道生成器として考える．SVCについては従来の技 術 [14] を用いて実現されるため詳しい議論はしない。

\subsection{TMG の機能}

ロボットシステムが高度なマニピュレーション機能を持つた めには, 機能に応じた複数のセンサフィードバック制御則と, 状態監視の結果に基づく制御則の切替え機能を具備する必要が ある．ある特定の制御則が駆動されている時，ロボットの動作 は特定のモードにあるとみなすことができる．このモードを動 作モードと呼ぶ. 必要な機能に応じて，様々な動作モードを用 意する必要があり, 各モードを実現する機能を, 設定パラメー タが明確な部品としてモジュール化することが有効である．こ のモジュールを動作モジュールと名付ける．モジュール化する ことにより再利用が容易になり，パラメータの設定により様々 な機能の実現の際に用いることができ汎用性が高まる．前節で
述べたツール操作指令值は, ベース指令值に対して相対的な位 置指令である．センサ情報に基づきこのツール操作指令值を 生成することにより，センサフィードバックの実現が可能であ る. そこで, 動作モジュールの出力はツール操作指令値とする. すなわち，動作モジュールは，センサ情報やコントローラの内 部情報, 事前に用意された動作パターン, さらにはこれらの情 報を複合処理した結果を用いてツール操作指令值を生成する． TMG は内部に複数の動作モジュールをもち，作業の状況に応 じ, 適切に駆動する動作モジュールを切替えながら適切なツー ル操作を実現する。

以上より TMG に必要な基本機能を以下にまとめる.

・複数の動作モジュールを内蔵する機能

- 作業の状況を監視する機能

・監視結果に基づき，作業を中断せずに動作モジュールを切 替える機能

ロボットが確実な作業を行うために，ロボットに自律的に学 習あるいは適応する能力を期待するよりも，まず，人の手によ り設計・修正することにより確実な作業を行うものを作り込む ことが有用である.マニピュレーション機能の設計の際には， 種々の不確実要因を考慮する必要があるが，すべてを予測する ことは事実上不可能である．そこで, 経験を通じて適宜修正し ていくことが不可欠になるが，その修正を容易に行えるシステ ムを作り上げる必要がある，以上のことを考慮し，機能分散を 重視した TMGの具体的なシステムアーキテクチャを次章以下 で述べる。

\section{3 ロボット作業に対する前提条件}

本論文で考えているマニピュレーション機能を実現するため には, 状況に応じて適切に動作モードを切替え, 不確実性に対 処する必要がある．すなわち，マニピュレーション機能の設計 の際には，どのような不確実性がどういった状況でおこり，そ の対処のために必要とされる適切な動作モードは何かを考慮し なければならない。そこで, 必要な動作モジュールの種類と， 各モジュールを駆動する条件を決定するために，以下の前提条 件を考える。

（1）一つの単位動作は, 有限の状態遷移によって表現するこ とができる。

（2）現在の状態とセンサ情報により，次に遷移する状態を決 定することができる

（3）各状態に対する動作は，適切なセンサ情報に基づいて実 現することができる

現実の作業において，作業プロセスを完全に反映するような 状態遷移や動作を，事前に把握することは困難である．最初に モデルの大枠を作っておき, 試行を通して実際の作業プロセス を反映させるようにモデルを変更していくことが現実的である． そのためには, 状態の種類や状態の遷移あるいは動作の追加・ 修正が容易な構成であることが必要となる．このように実際の 作業に応じたシステムの調節が容易なことは実用上重要であり， これは本システムの狙いの一つである。 


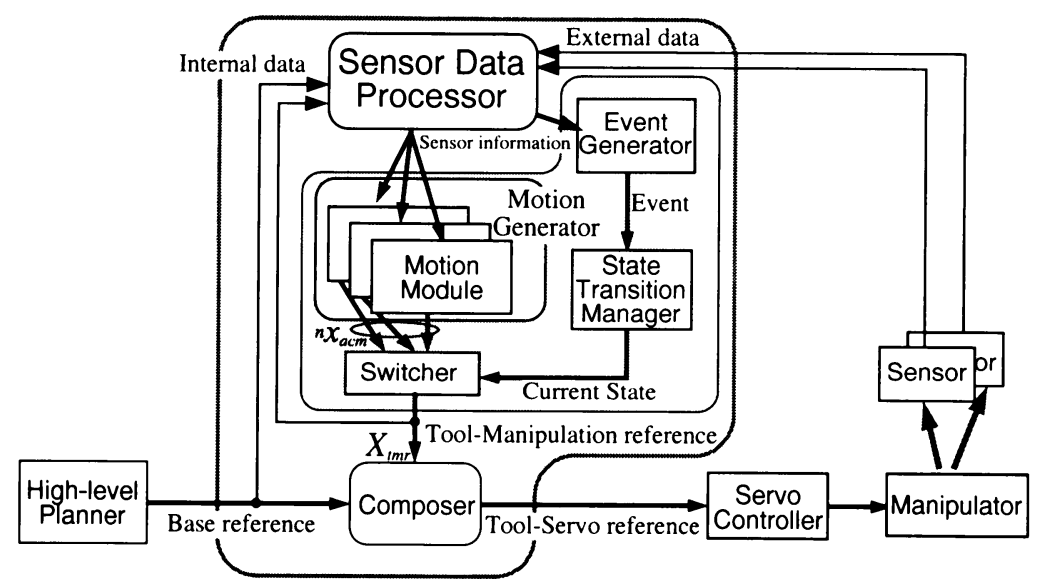

Fig. 3 Structure of MSM

\section{3. イベント駆動型動作モジュール切替機構}

\section{1 概要}

我々は, TMGの具体的なアーキテクチャとして, イベント 駆動型動作モジュール切替機構 (event-driven Motion-module Switching Mechanism-MSM) と呼ぶメカニズムを提案する. Fig. 3 にMSM の構造を示す. MSM は事前に用意しておいた 複数の動作モジュールを持つ. 各動作モジュールは, 特定の状 況で適切な特定の制御則により,ツール操作指令値を生成す る。また，MSM は作業のモデルとして状態遷移ネットワーク を持っており，作業の実行中に状態遷移ネットワークとセンサ 情報を用いて作業状態を決定する。この決定は，状態遷移の指 標となる“イベント”を生成することにより行われる，MSM は 作業状態に基づき, 複数のモジュールのなかから一つの動作モ ジュールを選択する．動作モジュールの選択および切替えは， 動作を中断せずに行われる

ここで状態遷移のチャタリングなどを防止した安定な状態遷 移を実現する必要がある．例えば，不安定な遷移が生じやすい 場合は，その過渡状態を新たな中間状態として設けることが有 効である。このように, 最終的な状態遷移の設計は試行的に行 うことが現実的であり, 状態の設定やイベントの生成ルールの 変更が容易に行える必要がある。また, 動作モジュール切替え 前後での運動指令值の連続性を確保しなければならない．そこ で，動作モジュールが MSM 自身の出力や上位プランナの出力 を，センサ情報と同様に用いることができる構成をとる。これ により各動作モジュール内で過去の出力の履歴を用いることが 可能となり，常に連続な指令値を生成することを保証できる.

\subsection{MSM の構成}

次に MSM の各ブロックとそれぞれの機能の詳細について述 べる.

\section{イベントジェネレータ（Event Generator）}

センサ情報から状態遷移を検出し, センサデータイベント マップ（SE-Map）に基づき，サーボサイクルと同程度のサイ クルでイベントを生成する.

状態遷移マネージャ(State Transition Manager)

イベントに基づいて, 状態遷移ネットワーク上で現在の状態
を同定する. 各イベント入力に対する状態の遷移先は, 前もって トランジッションイベントマップ (TE-Map) に登録しておく. モーションジェネレータ (Motion Generator)

モーションジェネレータは, $N$ 個の動作モジュール (Module $n ; n=1, \ldots, N)$ を持ち, それらは並列に動作している. 各モ ジュールは, センサ情報, 過去のツール操作指令値と自分自身 の過去の出力を用いて以下のようにツール操作指令値を生成す る. Module $n$ の動作はデジタル制御則で記述され, 式 (1) で 表されるような引数をもつ関数 ${ }^{n} G()$ により, 毎サンプル時刻 のツール操作指令值を生成する.

$$
\begin{gathered}
{ }^{n} \boldsymbol{x}_{a c m}[i]={ }^{n} G\left({ }^{n} \boldsymbol{x}_{a c m}[i-j], \boldsymbol{X}_{t m r}[i-j], \boldsymbol{S}[i-j]\right) \\
\text { ただし } j=1, \ldots, i
\end{gathered}
$$

ここで, [ ] 内はサンプリング番号を表し,$n$ はモジュール番号を 表す. $\boldsymbol{S}[*]$ はセンサ情報を示す. ${ }^{n} \boldsymbol{x}_{a c m}[i]$ はサンプル $i$ におけ る Module $n$ が出力するツール操作指令值である. ${ }^{n} \boldsymbol{X}_{t m r}[i-j]$ は $j$ サンプル過去においてスイッチャ(後述) が出力したツー ル操作指令値であり, サンプル $i-j$ においてスイッチャによ り選ばれた動作モジュールの出力に等しい.

\section{センサ情報プロセッサ（Sensor Data Processor）}

センサから得られる外部情報およびコントローラの内部情報 を処理し，モーションジェネレータやイベントジェネレータで 使用される情報を生成する。ここで，センサ情報プロセッサは 外部情報だけでなく，内部デー夕も同等の情報として処理可能 なことが重要な特長である．例えば，上記モーションジェネレー 夕内の各動作モジュールは，センサ情報の一種として $\boldsymbol{X}_{t m r}$ を 扱うことができる.その結果, 式 (1) の右辺の関数 ${ }^{n} G()$ の 引数はセンサ情報およびモジュールの内部情報とみなせ, 各モ ジュール内のみの処理でモジュール切替え前後において連続な ツール操作指令值を生成することができる，具体例を次章の設 計例で述べる.

\section{スイッチャ (Switcher)}

状態遷移マネージャによって同定された現在の状態に基づき， 動作モジュールの一つを選択する。その結果，選択されたモ ジュールにより生成されるツール操作指令值がコンポーザへ送 られる。 


\section{コンポーザ (Composer)}

ツール操作の基準位置となるベース指令值とツール操作指令 值の合成により，ツールが実際に追従すべきツールサーボ指令 值を生成し, サーボコントローラへ出力する.

\section{4. システム設計例}

本章では, トラッキング作業の一つであるバリ取り作業を例 にシステム設計例を示す。

\section{1 作業の概要}

Fig.4 に対象とするバリ取り作業の概要を示す. ワークは曲 線状の輪郭形状を有する平板であり，外縁部に様々なサイズ・ 硬さのバリをもつ．事前にバリの発生している正確な位置，サ イズを特定することは困難であり，このようなワークに対し単 一の制御モードだけでバリを除去することは難しい，例えば， 力一定の力制御だけでは硬いバリを除去できない可能性がある. コンプライアンス制御を用いると偏差が大きくなるにつれて作 用力も増大し，その結果としてツールが損傷する可能性も生じ る．このような問題を解決するためには種々のアプローチをと ることができるが，提案する MSM を用いれば，以下に示すよ うな手順によって見通し良くシステムを設計することができる．

\section{2 設計例}

まず，教示データとしてワークの外形と動作速度をベース指 令值の軌道として HLPに与え, 次に, バリの発生状況に応じ て次のように作業仕様を設定する。

（1）バリがほとんど生じていない場合：ワーク面に対して垂直 方向に微小な力 $\left(F_{T x}\right)$ を加えながらワーク面に做う。

(2) 除去に一定以上の力を加える必要があるバリが生じている 場合：ワーク面に対して垂直方向に一定の力 $\left(F_{D x}\right)$ を与 えることによりバリをとる．ここで，教示軌道（位置およ び姿勢）デー夕の軌跡としてワーク面の外形をあたえるの で，教示軌道がワーク面の方向を反映していることになる． 以下にこの作業仕様を実現する MSM の設計例を示す.

\section{[状態の設定 $]$}

バリの発生状況による二つの状態に加えて，これらの状態間 の過渡状態を考える（過渡状態の定義については付録-Bに述 べる)。ここで過渡状態を設定することは，状態遷移のチャ夕 リングを防止し，制御モードのスムースな移行を行わせること に有効である。

さらに，異常事態に対処するための保護状態を考える，バリ 取り作業のように，力を作用させる作業においては，力が作用

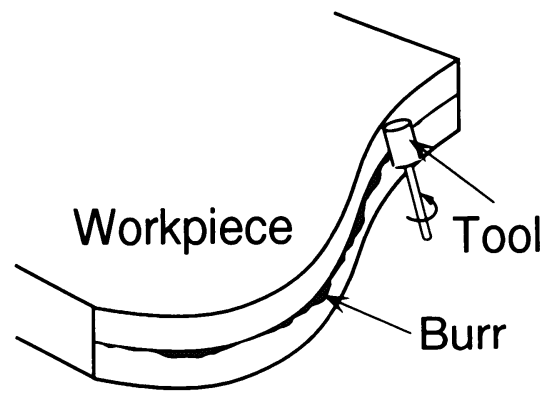

Fig. 4 Example task
するツールやワークが破損してしまうと制御指令值が発散して しまう可能性がある，保護状態を考えることにより，このよう な異常事態に対処する．以上のように Fig. 5 (a) に示す四つの 状態を設定する．ここでは，状態のイメージ図のみを示してお く．これらの四つの状態の設定の詳細については付録-Cに記 載しておく.

[動作モジュールの設定］

上記の作業仕様に基づき，三つの動作モジュールを用意する． ここでは力制御としてダンピング制御 [16]を用いる.

Module 1:ダンピングモジュール A

輪郭形状に追従させるため, 軌道垂直方向に微小力 $F_{T x}$ を作用させる。

Module 2:ダンピングモジュール B バリを除去するため，軌道垂直方向に力 $F_{D x}$ を作用さ せる。

Module 3：保護動作モジュール ツール操作指令值の更新を凍結する。

ここで, 各モジュールのツール操作指令值の生成法を, 簡単の ために $x$ 軸方向一次元の場合について以下に示す.

${ }^{n} \boldsymbol{x}_{a c m}(n=1,2,3)$ は各モジュールの出力するツール操作指 令值, $X_{t m r}$ はスイッチャが ${ }^{n} \boldsymbol{x}_{a c m},(n=1,2,3)$ から選び, コンポーザへ出力するツール操作指令值である.

また $A_{T}, A_{D}$ は適当なダンピング係数である.

\section{Module 1:}

$$
{ }^{1} x_{a c m}[i]=X_{t m r}[i-1]+A_{T}\left(f_{x}[i]-F_{T x}\right)
$$

\section{Module 2 :}

$$
{ }^{2} x_{a c m}[i]=X_{t m r}[i-1]+A_{D}\left(f_{x}[i]-F_{D x}\right)
$$

Module 3 :

$$
{ }^{3} x_{a c m}[i]=X_{t m r}[i-1]
$$

このように実際に MSM が利用した $X_{t m r}$ を各モジュール内で 用いることにより、ツール操作指令值の連続性を保証すること ができる．また，Module 1，2のようなセンサフィードバック 則だけでなく, Module 3 のような事前に設定した動作パター ンの生成も動作モジュールで実現することができる.

\section{[SM-Map の設定 $]$}

Fig. 5(b) に示すように，各状態（State 1-4）に対してモ ジュール（Module 1-3）をマッピングする. 各作業に対して, システムはデータベースとしてこれらのマップを管理する．

\section{[SE-Map の設定 ]}

Fig. 5 (c) に，センサデータからイベント生成ルールの設定例 を示す．状態遷移が生じたときに遷移先を決定するようなイべ ントが発生するのはもちろん，状態遷移が生じなかった場合も 現在の状態を維持するイベントが発生する。ツール操作座標系 における水平方向の力 $\left(f_{y}\right)$, ツール操作指令值の垂直方向成 分 $\left(X_{t m r}\right)$ ，およびこれらに対する闘值 $\left(F_{y o}, X_{o}, X_{1}\right)$ から イベントを生成する。これは, バリが生じている部分では進行 方向の力 $f_{y}$ が大きく, バリ除去直後ではツール操作指令值の 垂直方向成分 $X_{t m r}$ が残存している可能性があること，また， 
工具やワークが破損した非常事態では $X_{t m r}$ が発散していくと いうことを考慮した結果である.
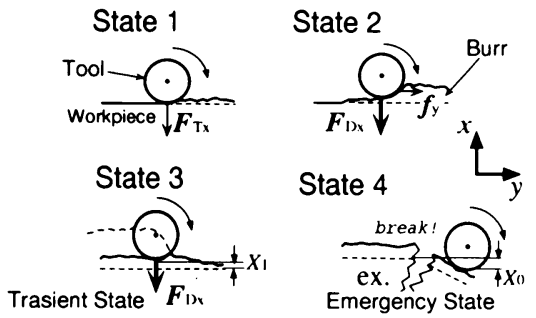

(a) State defnition

(b) State-to-Module Map (SM-map)

\begin{tabular}{|c|c|c|}
\hline State & $\begin{array}{c}\text { Driven } \\
\text { Module }\end{array}$ & Motion Mode \\
\hline State 1 & Module 1 & Damping Module A (small force) \\
State 2 & Module 2 & Damping Module B (large force) \\
State 3 & Module 2 & Damping Module B (large force) \\
State 4 & Module 3 & Protection Module (zero verocity) \\
\hline
\end{tabular}

(c) Sensor-data-to-Events Map (SE-map)

\begin{tabular}{|l|c|c|c|}
\hline Events & $X_{\mathrm{tmr}}<X_{\mathrm{o}}$ & $X_{\mathrm{o}}<X_{\mathrm{tmr}}<X_{1}$ & $X_{\mathrm{tmr}}>X_{1}$ \\
\hline$f_{\mathrm{y}}<F_{\mathrm{yo}}$ & \multirow{2}{*}{ Ev1 } & Ev2 & Ev3 \\
\hline & \multicolumn{2}{|c|}{ Ev4 } \\
\hline$f_{\mathrm{y}}>F_{\mathrm{yo}}$ & \multicolumn{2}{|c|}{} & \multicolumn{2}{|c|}{} \\
\hline
\end{tabular}

$X_{\mathrm{o}} X_{1}$ : Threshold of Tool Manipulation reference $F$ yo: Threshold of force data

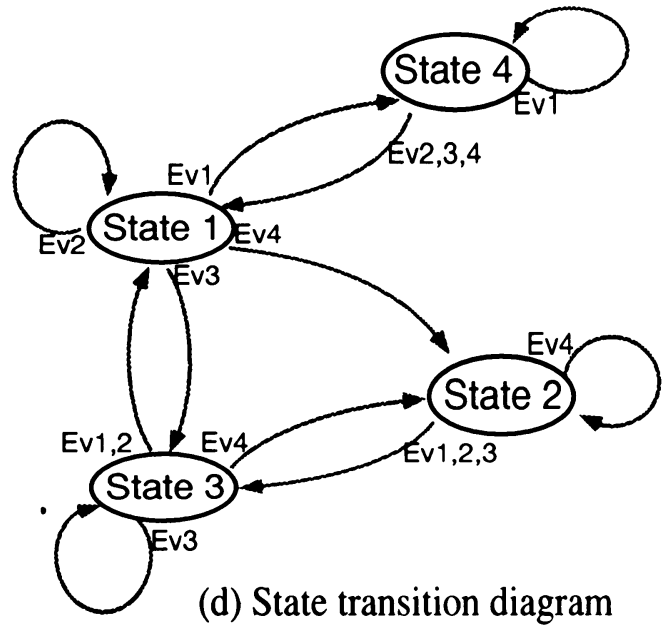

(e) Transition-to-Event Map (TE-map)

\begin{tabular}{|c|llll|}
\hline Current State & \multicolumn{4}{|c|}{ Next State } \\
\hline Event & Ev1 & Ev2 & Ev3 & Ev4 \\
\hline State 1 & St 4 & St 1 & St 3 & St 2 \\
State 2 & St 3 & St 3 & St 3 & St 2 \\
State 3 & St 1 & St 1 & St 3 & St 2 \\
State 4 & St 4 & St 1 & St 1 & St 1 \\
\hline
\end{tabular}

Fig. 5 Example of design

\section{[TE-Map の設定］}

Fig. 5 (d) に状態遷移ネットワークを示す，この図は，イベン トの状態遷移へのマッピングも示す．この状態遷移ネットワー クとイベントのマッピングは, Fig. 5 (e) に示されるマトリック スで表現される．このマトリックスは現在の状態が State 1 で あるとき, Event 3 の入力により, 状態は State 3 に変化する ことを意味する。このようにデータベースによる状態推移モ デルの表現により, 状態やイベントは容易に追加することがで きる。

上記の設計例はバリ取り作業を単純化してとらえた結果であ り，実際のバリ取り作業は上記の設計で満足いく結果が得られ るとは限らない。しかし，本設計例は，MSMの設計がデータ ベースで管理できるデータマップを作成することでできること を示すのが目的である．また，能力が不十分な場合は，MSM の設計に順次変更を加えていくことになるが，設定の修正が 容易なことも MSM の特徴である.すなわち，MSM の設計 は, Fig. 5 (b) (c) (e) に示される三つのデータマップ (SM-Map, SE-Map，TE-Map）を作成することであり，動作の修正には， この三つのマップを変更すればよい．これらのマップはデー夕 ベースとして保持できるので，処理の流れを変更することなく， 作業の修正ができる。このように，本システムを用いることに より，作業仕様を満足した動作を実行するモーション・コント ローラを見通し良く設計することができる。

\section{5. 実 験}

\section{1 実験システム}

実験システムの概要を Fig. 6 に示す. 本システムは機能分 散した構成をとるため, 並列処理が可能なリアルタイムシステ ムが必要となる。今回の実験システムでは，12 個のトランス ピュータを用いて MSM を構築した．トランスピュータを使う ことにより，マルチプロセッサー上での並列処理を行う実時間 システムを容易に実現することができた．ロボットとしては 6 自由度マニピュレータ PUMA260 を用いた。本マニピュレータ

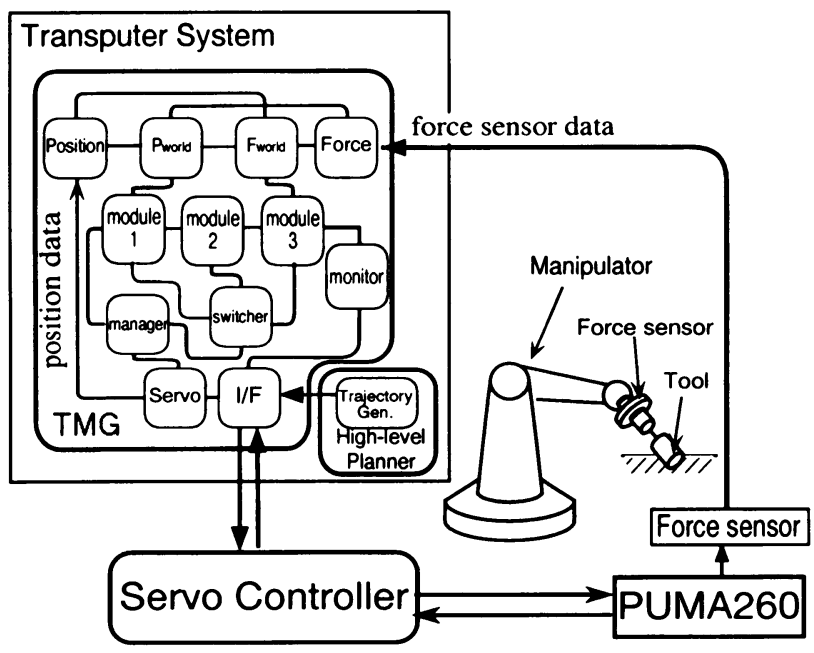

Fig. 6 Schematic of experimental system 


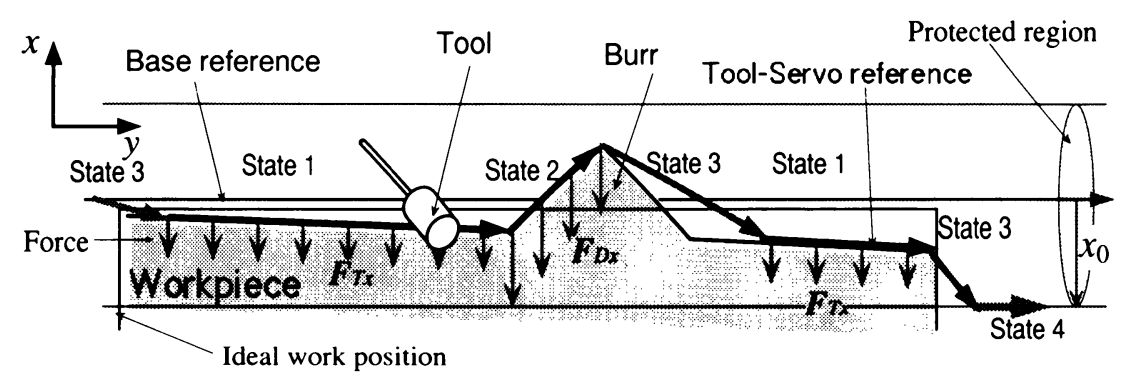

Fig. 7 Experimental task

はワールド座標系において位置制御されている．

現在のところ以下の 4 種類の動作モジュールを用意し，その うち三つを実行時に用いることができる.

(1) ダンピング制御モジュール

(2) コンプライアンス制御モジュール

(3) 保護モジュール

(ツール操作指令値の修正を抑制する)

(4) ツール操作量修正モジュール

(一定速度でツール操作指令值を減少する)

\section{2 実験作業}

実験では，4 章に示したバリ取りを単純化した以下のような 作業を行わせた（Fig.7）。単純なバリ状物体がワークに付随し ている．バリを除去するかわりに，この物体に垂直方向に一定 力を加える. 作業実行前に, 教示データとして直線軌道をべー ス指令値の軌道として与える。実行中にツールがバリ状物体 に接触しているとき, マニピュレータは物体に倣いつつ一定の 力 $\left(F_{D x}\right)$ を加える. ワークに接触しているときは, 小さな力 $\left(F_{T x}\right)$ でワークの外形を倣う。また，ワークの設置位置にも多 少の変動があることを想定する。

MSM の設計結果は, 状態の設定を Fig. 8(a)に, SE-Mapの 設定を Fig. 8 (b) に変更する以外 Fig. 5 と同じである. ダンピン グ制御による力制御の方向は進行方向に対して垂直方向 $\left(f_{x}\right)$ であり, バリ接触中か否かは主に進行方向の力 $\left(f_{y}\right)$ で判別を 行っている.

\section{3 実験結果}

Fig.9 に実験結果を示す. 図に示すように, ベース軌道とし ては片道 10 秒の往復運動を与えた. 設定力として $F_{T x}=5 N$, $F_{D x}=13 N$ を与えた． $X_{t m r}$ は, ベース軌道に対する垂直方 向のツール操作指令值である. $f_{x}$ と $f_{y}$ は垂直方向, 進行方向 の作用力である. 動作時間は片道 10 秒, 往復で 20 秒であり, $X_{t m r}$ の履歴, $f_{x}, f_{y}$ の履歴のグラフにおいて 10 秒までが往 路のデータである.10 秒のところで折り返し, それ以降が復路 のデータである。

ツールがバリ状物体に接触しないところでは, 指定した小 さな力 $\left(F_{T x}=5 N\right)$ でワークの外形を倣っている。ツールが バリと接触している間は, バリの表面に, 設定した適切な力 $\left(F_{D x}=13 N\right)$ を加えている.この結果は, 設計したとおりに 切替えが行われ, 適切な動作モジュールが駆動されていること を示している. (a) State defnition

\begin{tabular}{|l|l|}
\hline State 1 & Tracking Workpiece Contour \\
State 2 & Hitting Burr \\
State 3 & Transient State \\
State 4 & Emergency State \\
\hline
\end{tabular}

(b) Sensor-data_to_Events Map (SE-map)

\begin{tabular}{|c|c|c|c|}
\hline \multirow{2}{*}{} & $X_{\mathrm{tmr}}<X_{\mathrm{o}}(<0)$ & \multicolumn{2}{|c|}{$X_{\mathrm{o}}<X_{\mathrm{tmr}}$} \\
\cline { 2 - 4 } & & $f_{\mathrm{x}}>F_{\mathrm{xo}}$ & $f_{\mathrm{x}}<F_{\mathrm{xo}}$ \\
\hline$f_{\mathrm{y}}<F_{\mathrm{yo}}$ & \multirow{2}{*}{ Ev1 } & Ev2 & Ev3 \\
\cline { 3 - 4 } & \multicolumn{2}{|c|}{ Ev4 } \\
\hline$f_{\mathrm{y}}>F_{\mathrm{yo}}$ & & \multicolumn{2}{|c|}{} \\
\hline
\end{tabular}

$X$ o,: Threshold of Tool Manipulation reference $F$ xo, $F$ yo: Threshold of force data

Fig. 8 Design of experimental task

\section{6. ま と め}

マニピュレーション機能のインプリメントを容易にする運動 制御システムについて述べ, 具体的なアーキテクチャとして, 動作モジュール切替機構（MSM）を提案した.

MSM の特長は以下のとおりである.MSM はセンサ情報に 基づき動作モジュールをリアルタイムで切替えることにより， 環境の状況に応じた適切な動作を生成する。また，様々なセン サフィードバック則を動作モジュールとして実現するため, 様々 な制御則を汎用的に用いることができる。機能分散したアーキ テクチャ構成をとることにより，モジュラリティが高く，設計 パラメータが明確で機能の修正・拡張が容易である。さらに， バリ取り作業を扱う MSM の設計例を述べ, MSM の妥当性・ 実現可能性を実験的に示した。

提案した MSM はマニピュレーション機能を実現するための テンプレートであり，セットするモジュールの中身を入れ換え ることにより, 複数のマニピュレーション機能を実現できる. これにより，一連の動作からなる作業を実現することができる． 今後は, 実装できる機能のバリエーションを増やすとともに， 本システムの適用領域を明確にしていく．また，MSM の設計 に有効なヒューマンインタフェースについても検討する. 

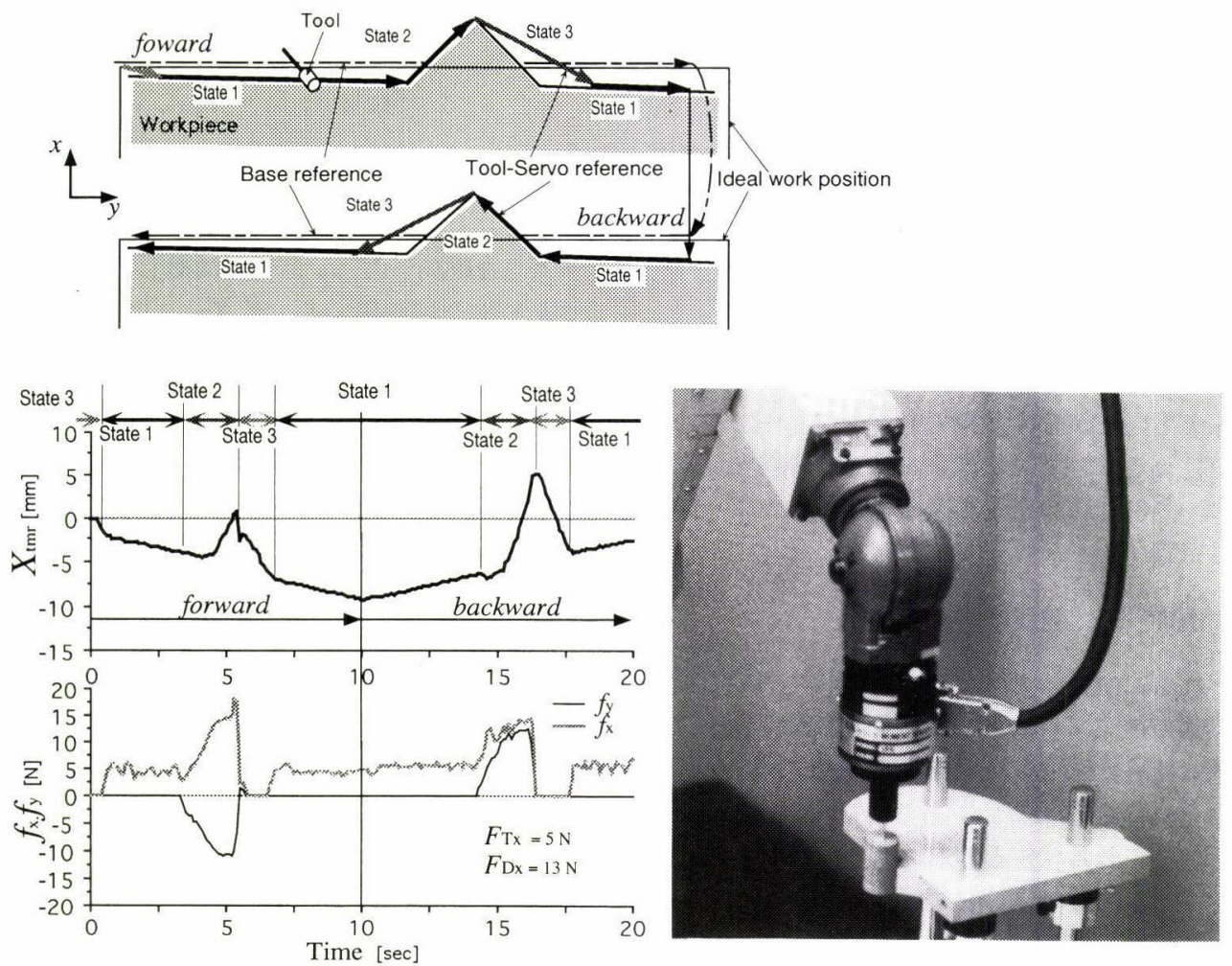

Fig.9 Experimental result

謝

辞

本研究を進めるにあたり，適切な助言をいただいた NTT コ ミュニケーション科学研究所大里延康グループリーダ, 同アク セス網研究所辻村健博士に感謝いたします。また, 日頃討論を していただく, 知能ロボット研究部の皆様に感謝します.

\section{参 考 文 献}

[1] “特集センサペースト・インダストリアルロボット”, 日本ロボット学 会誌, vol.9, no.3, 1991.

[2 ] H. Asada, C.C. Federspiel and S. Liu: "Human Centered Control in Robotics and Consumer Product Design," Trans. the ASME Journal of Dynamic Systems, Measurement, and Control, vol.115, no.6, pp.271-280, 1993

[3] 末広, 高瀬：“スキルに基づくマニピュレーションシステム”, 日本口 ボット学会誌, vol.8, no.5, pp.551-562, 1990.

[4] 下倉, 武藤：“接触状態変化検出機能を有するマニピュレーションシス テムに関する検討”, 日本ロボット学会誌，vol.12, no.6, pp.837-845, 1994.

［5］沢崎, 井上：“多指ハンドによる物体の転がし操作”，日本ロボット学 会誌, vol.9, no.5, pp.560-571, 1991.

[6] S. Muto and K. Shimokura: "Teaching and Control of Robot Contour-Tracking Using Contact Point Detection," Prof. of 1994 IEEEInternational Conference on Robotics and Automation, vol.1, pp.674-681, 1994

[7] 松尾, 久保田, 下倉, 三ッ矢, 水川：“ロボット作業におけるッール 操作の記述と制御法の検討”, 第 12 回日本ロボット学会学術講演会予 稿集, no.1, pp.313-314, 1994

[ 8 ] K. Kosuge, K. Furuta and T. Yokoyama,: "A Control Architec ture for Intelligent Mechanical System: Virtual Internal Mode Following Control," Proc. of 1987 IEEE International Symposium on Intelligent Control, pp.489-494, 1987.

[9 ] B.J McGrragher and H. Asada: "A Discrete Event Approach to the
Control of Robotic Assembly Tasks," Proc. of the 1993 IEEE International Conference on Robotics and Automation, vol.1, pp.331336, 1993

[10] D.M. Lyons and A.J. Hendriks: "Planning for Reactive Robot Behavior," Proc. of the 1992 IEEE International Conference on Robotics and Automation, vol.3, pp.2675-2680, 1992.

[11] J.S. Albus: “A Theory of Intelligent Systems," Proc. of 1990 IEEE International Conference on Intelligent Control, vol.PA, pp.866873,1990

[12] C. Luh and B.P. Zeigler: "Abstracting Event-Based Control Models for High Autonomy Systems," IEEE Trans. on Systems, Man, and Cybernetics, vol.23, no.1, pp.42-54, 1993.

[13] 柴田, 福田：“階層行動アーキテクチャ”, 日本ロボット学会誌, vol.11, no.8, pp.1111-1117, 1993

[14] 吉川恒夫：ロボット制御基礎論，コロナ社, 1988.

[15] J.K. Salisbury: "Active Stiffness Control of a Manipulator in Cartesian Coordinate," Proc. of the 19th IEEE Conference on De cision and Control, pp.95-100, 1980

[16] D.E. Whitney: "Historical Perspective and State of the Art in Robot Force Control," International Journal of Robotics Research, vol.6, no.1, pp.3-14, 1987.

\section{付録-A．マニピュレーション機能}

一般的にマニピュレーションといえば, 物体の把持・操りな ど，ハンドによる物体操作を意味することもあるが，本論文で はロボット作業として組立・加工作業を考え, その範疇でマニ ピュレーションを考える。組立・加工作業は，ロボット手先の ハンドが持つ部品や工具を操作することにより，ロボットの外 界に扔かれた作業対象へ作用を及ほしながら，組立・加工を行 うことである。そこで，ロボットのハンドに持つ部品やエンド・ エフェクタとしての工具など，ロボットが手先に装着している ものを“ツール”と呼び，作用を及ぼされるロボット外部にお 
かれた作業対象を“ワーク”と呼ぶことにする（Fig. 1) [6]. す ると, ロボットのマニピュレーションは「ッールを操作するこ とにより，ワークに作用を及ほすると」と言え，マニピュレー ション作業の高度化とはツールを使いこなす機能の高度化とと らえることができる．ここで，“作用を及ぼすこと”とは，加工 したり作用力を及ぼすという意味にとどまらず，ワークに対し て非接触で相対的な位置決めを行うといった，作用力を加える ための前段階の動作も広く“作用を及ぼすこと”と捉える。ま た，ロボットのマニピュレーションを高度化するためには内部・ 外部のセンサ情報を用いた状態の監視やセンサフィードバック 制御が必要となる。そこで，マニピュレーション機能を「セン サ情報を用い, ワークに適切な作用を及ぼすように, ツールを 操作する機能」と定義する.

\section{付録-B. 過渡状態の定義}

隣接すると思われる二つの状態 $\mathbf{A} ， \mathbf{B}$ が明確に定義できたと する。しかし，実際の作業プロセスを完全に離散的な状態に区 分することは困難な場合がある，そこで，定義した状態 $\mathbf{A}, \mathbf{B}$ の間でどちらか明確に区別しにくい，あるいは， $\mathbf{A} ， \mathbf{B}$ どちら の状態でもないと考えられる状況が生じる場合, その状況をま とめて過渡状態 $\mathrm{C}$ と定義する， A， B の二つの状態が明確に定 義できていれば，その間の状態で，どちらの状態でもない状態 を過渡状態 $\mathrm{C}$ と定義できる。

\section{付録-C. MSM 設計例における状態設計の詳細}

State 1 はバリがほとんど生じておらず, ワークの輪郭を倣つ ている状態であり, ツール操作指令值は $X_{t m r} \approx 0$ である.

State 2 はある程度のバリが生じていて, かつ, 進行方向から 抗力をうけながらパリを削っている状態と定義する。これらの
状態を $f_{y}, X_{t m r}$ を状態量に用いて以下のように定義する.

State 1: $f_{y} \leq F_{y o}, \quad X_{t m r} \leq X_{1}$

State 2: $f_{y}>F_{y o}$

ここで, $f_{y}$ は Tool が進行方向に受ける力, $F_{y o}$ は $f_{y}$ に対す る適当な閾値， $X_{t m r}$ は経路に対して垂直方向に出力している ツール操作指令值， $X_{1}$ は $X_{t m r}$ に対する適当な閾值である. 過渡状態 State 3 は Fig. 5 (a) に見るように

State 3: $f_{y}<F_{y o}, \quad X_{t m r}>X_{1}$

と定義する。 また, ツールあるいはワークが破損した場合, 力 を加えている方向にツール操作指令值が発散する。逆に正常な 状態で到達するツール操作指令值 $X_{t m r}$ の絶対值の最大サイズ を設定し，それ以上になったときは異常状態であると考える. 本作業例では $x$ 軸方向負方向に力を加えているので， $X_{t m r}$ の 負の閾值 $X_{o}(<0)$ を考え, ツール操作指令值を状態量として 異常状態 State 4 を次のように定義する。また,これに伴い

State 1 の定義も修正する.

State $1^{\prime}: f_{y} \leq F_{y o}, \quad X_{0} \leq X_{t m r} \leq X_{1}$

State $4: X_{t m r}<X_{0}(<0)$

以上まとめると，

- State 1: $f_{y} \leq F_{y o}, X_{0} \leq X_{t m r} \leq X_{1}$

- State 2: $f_{y}>F_{y o}$

- State 3: $f_{y}<F_{y o}, X_{t m r}>X_{1}$

- State 4: $X_{t m r}<X_{0}(<0)$

が設計例の状態の定義となる.

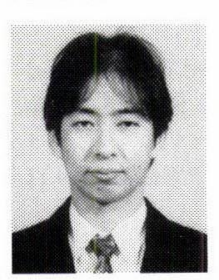

員.

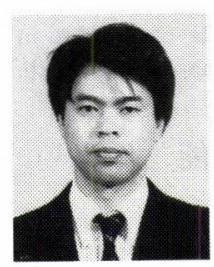

事.
片山幸久 (Yukihisa Katayama)

1966 年 3 月 20 日生. 1989 年名古屋大学工学部電子 機械工学科卒業, 1991 年同大学大学院工学研究科情 報工学専攻博士課程前期課程修了. 同年 4 月 NTT 入社. 知能ロボットシステムおよび知能ロボット用 センサの研究開発に従事. 現在 NTT ヒューマンイ ンタフェース研究所研究主任. 計測自動制御学会会

(日本ロボット学会正会員)

下倉健一朗 (Ken-ichiro Shimokura)

1959 年 4 月 1 日生. 1982 年早稲田大学工学部機械 工学科卒業, 1984 年同大学大学院理工学研究科博 士前期課程修了, 同年電電公社入社. 現在 NTT ヒューマンインタフェース研究所主任研究員.こ の間 1993〜1994 年マサチューセッツ工科大学客員 研究員. 知能ロボットシステムに関する研究に従 （日本ロボット学会正会員）

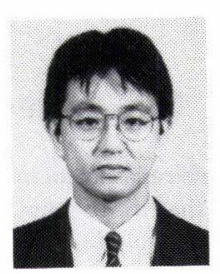

南條義人（Yoshito Nanjo）

1961 年 8 月 24 日生. 1987 年早稲田大学大学院理 工学研究科修士課程（機械工学専攻）修了, 同年 4 月 NTT 入社. 現在 NTTヒューマンインタフェー ス研究所主任研究員、ロボットの運動制御扔よび システムの研究に従事. 日本機械学会会員。

(日本ロボット学会正会員) 